\title{
Menguji Pengaruh Pendidikan Kewirausahaan dalam Pembentukan Jiwa Wirausaha di Kalangan Mahasiswa
}

\author{
M. Rudi Irwansyah ${ }^{1 *}$, Lulup Endah Tripalupi ${ }^{2}$
}

12 Universitas Pendidikan Ganesha, Singaraja - Indonesia

\section{A R T I C L E I N F O}

Article history:

Received 25 August 2018

Received in revised form 02 October 2018

Accepted 20 October 2018

Available online 29

November 2018

Kata Kunci:

Pendidikan Kewirausahaan,

dan Jiwa Kewirausahaan

Keywords:

Entrepreneurship

Education, and

Entrepreneurial Spirit

\begin{abstract}
A B S T R A K
Penelitian ini bertujuan untuk mengetahui pengaruh pendidikan kewirausahaan dalam membentuk jiwa kewirausahaan dan besar pengaruh pendidikan kewirausahaan dalam membentuk jiwa kewirausahaan di kalangan mahasiswa Undiksha. Rancangan penelitian ini adalah penelitian kausalitatif. Populasi dalam penelitian ini yaitu seluruh mahasiswa Undiksha yang telah menempuh mata kuliah kewirausahaan yang berjumlah 1861 orang, sedangkan sampel yang diambil berjumlah 329 orang.Pengumpulan data dilakukan dengan metode kuesioner. Data yang diperoleh tersebut kemudian dianalisis dengan analisis regresi linier sederhana.Hasil dari penelitian ini menunjukkan bahwa pendidikan kewirausahaan berperan dalam membentuk jiwa kewirausahaan mahasiswa Undiksha, besar pengaruh pendidikan dalam membentuk jiwa kewirausahaan adalah sebesar $10,9 \%$ dan sisanya dipengaruhi oleh faktor lain yang tidak diperhitungkan dalam penelitian.
\end{abstract}

\section{A B S T R A C T}

This study aims to determine the effect of entrepreneurship education in shaping the entrepreneurial spirit and the influence of entrepreneurship education in shaping entrepreneurial spirit among Undiksha students. The design of this study is causal research. The population in this study were all Undiksha students who had taken entrepreneurship courses totaling 1861 people, while the samples taken amounted to 329 people. Data collection was done by questionnaire method. The data obtained are then analyzed by simple linear regression analysis. The results of this study indicate that entrepreneurship education plays a role in shaping the entrepreneurial spirit of Undiksha students, the influence of education in shaping entrepreneurial spirit is $10.9 \%$ and the rest is influenced by other factors not taken into account in research.

\footnotetext{
* Corresponding author.

E-mail addresses: rudi.irwansyah@undiksha.ac.id (M. Rudi Irwansyah),
} 


\section{Pendahuluan}

Perguruan Tinggi merupakan tempat untuk mendidik mahasiswa agar memiliki kemampuan intelektual dan keterampilan yang memadai sebagai bekal kehidupannya di masa mendatang. Hal ini telah diamanatkan oleh Undang-undang Dasar Negara Indonesia tentang upaya mencerdaskan kehidupan bangsa, bahwa setiap warga negara usia sekolah mulai dari tingkat dasar hingga perguruan tinggi harus mengenyam pendidikan. Dalam visi pembangunan pemerintah menargetkan terwujudnya Indonesia yang berdaulat, mandiri, dan berkepribadian berlandaskan gotong royong dengan cara mewujudkan bangsa yang memiliki daya saing (Nasir, 2016). Dengan demikian pendidikan tinggi mempunyai peran yang sangat strategis dalam menyiapkan sumberdaya manusia sebagai penggerak pembangunan bangsa.

Sumber daya manusia yang unggul akan mendorong pertumbuhan bangsa baik dalam bidang ilmu pengetahuan, teknologi maupun sektor ekonomi. Pertumbuhan Ekonomi yang baik haruslah ditopang oleh kerjasama pemerintah dan sektor pengusaha, sehingga kedua sector iniharus tumbuh bersama-sama (Thaddeus, 2012).Karena sesungguhnya pertumbuhan ekonomi itu sangat berkaitan dengan kemampuan Negara untuk membangun sumber daya manusia, keuangan, modal, fisik dan alam untuk menghasilkan barang dan jasa yang dapat dipasarkan (Al-Mubaraki \& Busler, 2013). Untuk itulah perguruan tinggi perlu menyiapkan lulusannya agar mampu menciptakan peluang tersebut. Semakin banyak lulusan perguruan tinggi yang bisa menciptakan pekerjaan sendiri, akan membuat perkembangan ekonomi semakin pesat khususnya dalam menyediakan lapangan pekerjaan. Hampir disetiap Negara di seluruh dunia telah memiliki cara untuk mengembangkan keinginan wirausaha masyarakatnya (Gangi \& Timan, 2013). Hal ini sejalan dengan program pemerintah sebagai salah satu program nawacita yaitu mewujudkan kemandirian ekonomi dengan menggerakkan sector-sektor strategis ekonomi domestic (Nasir, 2016).

Secara umum, pendidikan memberikan dampat pada pembentukan jiwa wirausaha (Robinson \& Sexton, 1994).Berwirausaha merupakan peluang yang menjamin bagi seorang sarjana untuk memiliki penghasilan sendiri dan membantu menciptakan lapangan pekerjaan bagi orang lain. Menurut Alma (2005:6) "dengan bekal pendidikan tinggi yang diperoleh di bangku kuliah dan idealisme yang terbentuk, lulusan perguruan tinggi diharapkan mampu mengembangkan diri menjadi seorang wirausahawan". Pendidikan kewirausahaan memberikan motivasi, ilmu pengetahuan dan keahlian kepada siswa untuk menjadikan sebuah usaha menjadi sukses (Minniti \& Lévesque, 2008). Oleh sebab itu, perlu ditanamkan jiwa kewirausahaan kepada mahasiswa dengan memberikan pengetahuan kewirausahaan, baik dengan cara memasukan pendidikan kewirausahaan ke dalam kurikulum inti maupun dengan cara memberikan pelatihan-pelatihan kewirausahaan.

Banyak peneliti berpendapat bahwa kewirausahaan seperti lapangan tanpa batas yang jelas dan tidak memiliki kerangka konseptual yang jelas(Bruyat \& Julien, 2001; Busenitz et al., 2003; Ireland \& Webb, 2007; Shane \& Venkataraman, 2000). Namun secara umum wirausaha dapat diartikan sebagai seseorang yang mampu mengorganisasikan, mengatur dan mengasumsikan resiko dalam sebuah bisnis (Wolf, 1980). Secara sederhana wirausaha (entreprenur) adalah orang yang berjiwa berani mengambil resiko untuk membuka usaha dalam berbagai kesempatan berjiwa berani mengambil resiko artinya bermental mandiri dan berani. Menurut Basrowi (2014:4), "wirausaha adalah orang-orang yang mempunyai kemampuan melihat dan menilai kesempatan-kesempatan bisnis, mengumpulkan sumber daya-sumber daya yang dibutuhkan guna mengambil keuntungan dan tindakan yang tepat guna dalam memastikan kesuksesan". Kasmir (2006), menyatakan wirausahawan adalah orang yang berjiwa berani mengambil resiko untuk membuka usaha dalam berbagai kesempatan. Dalam keberanian mengambil resiko untuk membuka usaha tentunya membutuhkan kreativitas dan inovasi dengan memperhitungkan peluang (kesempatan) yang ada. Memiliki kreativitas dan inovasi seorang wirausahawan tidak cukup dalam memperhitungkan peluang yang ada, namun diperlukan adanya kecerdasan dalam membaca peluang tersebut

Namun demikian kewirausahaan tidak serta merta berkembang begitu saja, sehingga diperlukan usaha yang sungguh-sungguh agar dapat menumbuhkan kewirausahaan tersebut. Usaha yang dilakukan bisa saja dengan memberikan pengetahuan kewirausahaan, baik dengan cara memasukkan pendidikan kewirausahaan kedalam kurikulum inti maupun dengan cara memberikan pelatihan-pelatihan kewirausahaan. sama halnya dengan program pendidikan atau pelatihan-pelatihan yang melibatkan pengembangan kualitas pribadi seseorang, pendidikan kewirausahaan dapat memberikan stimulus dalam pengembangan jiwa wirausaha (Fayole et al, 2006).Pengetahuan kewirausahaan melalui pendidikan tersebut diharapkan dapat membentukjiwa kewirausahaanmahasiswa. Pendidikan kewirausahaan tersebut diharapkan dapat senantiasa membangun dan mengarahkan kemampuan serta minat para lulusan perguruan tinggi untuk bergerak dan mengembangkan kewirausahaan sehingga lapangan pekerjaan yang sedikit tidak menjadi masalah bagi para lulusan, karena mereka sudah mampu untuk menjalankan usahanya sendiri.. 
Solomon dan Fernald (dalam Merry, 2007) serta Hisrich dan Peters (dalam Bell, 2008), menyatakan bahwa pendidikan kewirausahaan masih memfokuskan pada penyusunan rencana bisnis, bagaimana mendapatkan pembiayaan, proses pengembangan usaha dan manajemen usaha kecil. Selain itu, pendidikan tersebut juga memberikan pengetahuan mengenai prinsip-prinsip kewirausahaan dan keterampilan teknis bagaimana menjalankan bisnis. Akan tetapi, pengetahuan mengenai prinsip-prinsip kewirausahaan dan pengelolaan bisnis tersebut belum tentu dapat menciptakan seorang wirausaha yang sukses. Oleh sebab itu, mereka perlu dibekali dengan berbagai atribut, keterampilan dan perilaku yang dapat meningkatkan kemampuan kewirausahaan mereka. Jadi, mata kuliah kewirausahaan perlu dirancang secara khusus untuk dapat mengembangkan karakteristik kewirausahaan sehingga diperlukan perubahan sistem pendidikan kewirausahaan. Tantangan dalam menjalankan sistem pendidikan tersebut adalah bagaimana sistem pembelajaran yang dapat mengembangkan diri dalam hal keterampilan, atribut dan sekaligus karakteristik perilaku seorang wirausaha dikalangan peserta didik.

Universitas Pendidikan Ganesha sebagai salah satu perguruan tinggi di Indonesia juga berusaha untuk ikut serta dalam menciptakan wirausahawan-wirausahawan di kalangan generasi muda. Mata kuliah kewirausahaan telah dimasukkan ke dalam kurikulum inti.Matakuliah kewirausahaan wajib di tempuh mahasiswa dari berbagai Jurusan.Ini merupakan salah satu bukti bahwa Undiksha berpartisipasi untuk mencetak lulusan yang memiliki jiwa wirausaha. Pendidikan kewirausahaan tersebut diharapkan dapat mengembangkan karakteristik kewirausahaan di kalangan mahasiswa.

Menurut Azwar (2007) faktor-faktor yang mempengaruhi sikap adalah pengalaman pribadi, pengaruh orang lain yang dianggap penting, pengaruh kebudayaan, media massa, lembaga pendidikan dan lembaga agama, dan pengaruh faktor emosional. Selain itu, pembentukan dan perubahan sikap akan ditentukan oleh dua faktor, yaitu faktor internal dan faktor eksternal (Walgito, 2003). Faktor internal (individu itu sendiri) berarti cara individu dalam menanggapi dunia luar dengan selektif sehingga tidak semua yang datang akan diterima atau ditolak, sedangkan faktor eksternal berarti keadaan-keadaan yang ada di luar individu yang merupakan stimulus untuk membentuk atau mengubah sikap. Sementara itu Mednick (1975) menyebutkan bahwa pembentukan sikap dipengaruhi oleh tiga faktor, yaitu pengaruh sosial (seperti norma dan kebudayaan), karakter kepribadian individu, serta informasi yang selama ini diterima individu.

Sikap kewirausahaan yang dimaksud dalam penelitian ini diadopsi dari definisi Tawardi (1999), yaitu kesiapan seseorang untuk merespon secara konsisten terhadap aspek karakteristik yang dimiliki oleh seorang wirausaha. Menurut Drucker (1994) menyatakan bahwa kewirausahaan lebih merujuk pada sifat, watak, dan ciri-ciri pada seseorang yang mempunyai kemauan keras untuk mewujudkan gagasan inovatif dalam dunia usaha dan dapat mengembangkannya dengan tangguh.

Tujuan penelitian ini adalah untuk mengetahui pengaruh pendidikan kewirausahaan dalam membentuk jiwa kewirausahaan, dan untuk mengetahui besar pengaruh pendidikan kewirausahaan dalam membentuk jiwa kewirausahaan mahasiswa Universitas Pendidikan Ganesha.

\section{Metode}

Penelitian ini menggunakan rancangan penelitian kausal, yaitu untuk mengetahui pengaruh pendidikan kewirausahaan terhadap pembentukan jiwa wirausaha mahasiswa Universitas Pendidikan Ganesha. Populasi dalam penelitian ini adalah seluruh mahasiswa Undiksha. Sampel diambil dengan proporsional random sampling. Sampel diambil dengan menggunakan rumus Slovin. Kuesioner digunakan untuk mengumpulkan data Pendidikan Kewirausahaan dan kesiapan kewirausahaan

\section{Hasil dan Pembahasan}

Berdasarkan hasil analisis regresi linier sederhana tentang pengaruh pendidikan kewirausahaan dalam membentuk jiwa kewirausahaan mahasiswa Universitas Pendidikan Ganesha diperoleh $t_{h i t u n g}$ sebesar 6,314 dengan taraf signifikan 0,000. Maka dapat disimpilkan bahwa Ho ditolak.Hal ini berarti terdapat pengaruh pendidikan kewirausahaan dalam membentuk jiwa kewirausahaan mahasiswa Universitas Pendidikan Ganesha secara positif dan signifikan.Hasil analisis regresi linier tersebut dapat ditunjukkan pada tabel berikut. 
Tabel 1 Hasil Analisis Pengaruh Pendidikan Kewirausahaan dalam Membentuk Jiwa Kewirausahaan Mahasiswa Universitas Pendidikan Ganesha.

\begin{tabular}{|c|c|c|c|c|c|}
\hline \multicolumn{2}{|c|}{ Variabel } & \multirow{2}{*}{$\begin{array}{c}\begin{array}{c}\text { Unstandardized } \\
\text { Coefficient }\end{array} \\
\text { B } \\
\end{array}$} & \multirow{2}{*}{$\mathbf{t}$} & \multirow{2}{*}{ Sig } & \multirow{2}{*}{$\begin{array}{c}\text { Keteranga } \\
\mathbf{n}\end{array}$} \\
\hline Bebas & Terikat & & & & \\
\hline Constant & \multirow[b]{2}{*}{$\begin{array}{c}\text { Jiwa } \\
\text { Kewirausahaan }\end{array}$} & 12,934 & 21,155 & 0,000 & Signifikan \\
\hline $\begin{array}{c}\text { Pendidikan } \\
\text { Kewirausahaan }\end{array}$ & & 0,357 & 6,314 & 0,000 & Signifikan \\
\hline
\end{tabular}

Sumber: Data diolah Peneliti, 2017

Hal ini menunjukkan bahwa pelaksanaan pendidikan kewirausahaan memberikan manfaat yang positif pada sikap kewirausahaan mahasiswa. Hasil penelitian ini membuktikan relevansi dari teori yang dikemukakan oleh Green (1972) yaitu terdapat faktor predisposisi (faktor yang mempermudah) terbentuknya sikap seperti pengetahuan, keyakinan, kepercayaan, nilai-nilai, dan tradisi. Selain ini hasil penelitian ini juga memperkuat penelitian sebelumnya yang dilakukan oleh Mulyadi (2010) yang memperoleh hasil (1) pendidikan berpengaruh positif dan signifikan terhadap sikap kewirausahaan; (2) pendidikan dan sikap secara langsung terhadap perilaku berwirausaha; (3) pendidikan melalui sikap berpengaruh positif dan signifikan terhadap perilaku kewirausahaan.Kemudian penelitian lain yang sejenis yaitu penelitian yang dilakukan oleh Kourilsky, M.L. dan Walstad.

Berdasarkan hasil penelitian ini, diketahui bahwa peranan pendidikan kewirausahaan dalam membentuk jiwa kewirausahaan dikalangan mahasiswa undiksha sebesar 10,9\% dan sisanya dipengaruhi oleh faktor lain. Hal ini dapat dilihat dari hasil nilai R square berikut.

Tabel 2. Besar Pengaruh Pendidikan Kewirausahaan damalm Membentuk Jiwa Kewirausahaan

\section{Model Summary ${ }^{\mathrm{b}}$}

\begin{tabular}{|c|c|c|c|c|}
\hline Model & $\mathrm{R}$ & R Square & Adjusted R Square & Std. Error of the Estimate \\
\hline 1 & $.330^{\mathrm{a}}$ & .109 & .106 & 1.96083 \\
\hline
\end{tabular}

a. Predictors: (Constant), Pendidikan Kewirausahaan

b. Dependent Variable: Jiwa Kewirausahaan

Faktor-faktor yang mempengaruhi sikap adalah pengalaman pribadi, pengaruh orang lain yang dianggap penting, pengaruh kebudayaan, media massa, lembaga pendidikan dan lembaga agama, dan pengaruh faktor emosional (Azwar, 2007). Selain itu, pembentukan dan perubahan sikap akan ditentukan oleh dua faktor, yaitu faktor internal dan faktor eksternal (Walgito, 2003). Faktor internal (individu itu sendiri) berarti cara individu dalam menanggapi dunia luar dengan selektif sehingga tidak semua yang datang akan diterima atau ditolak, sedangkan faktor eksternal berarti keadaan-keadaan yang ada di luar individu yang merupakan stimulus untuk membentuk atau mengubah sikap. Sementara itu Mednick (1975) menyebutkan bahwa pembentukan sikap dipengaruhi oleh tiga faktor, yaitu pengaruh sosial (seperti norma dan kebudayaan), karakter kepribadian individu, serta informasi yang selama ini diterima individu.

\section{Simpulan dan Saran}

Berdasarkan hasil penelitian, maka dapat diambil simpulan bahwatelah terbentuk Jiwa kewirausahaan pada mahasiswa yang telah mengikuti mata kuliah kewirausahaan. Jiwa kewirausahaan yang muncul pada diri mahasiswa, seperti percaya diri, berorientasi pada tugas dan hasil, pengambilan risiko, kepemimpinan, keorisinilan, dan berorientasi pada masa depan.Besarnya peranan pendidikan kewirausahaan dalam membentuk jiwa kewirausahaan dikalangan mahasiswa Undiksha adalah sebesar 10,9\% dan sisanya dipengaruhi oleh faktor lain yang tidak diperhitungkan dalam penelitian ini.

Berdasarkan hasil penelitian, maka saran yang diberikan adalah pelaksanaan pembelajaran pendidikan kewirausahaan di Undiksha agar lebih ditingkatkan. Tujuan pembelajaran hendaknya dirumuskan secara jelas dalam bentuk perilaku atau kinerja sehingga dapat diamati dan diukut, dengan demikian dapat diketahui efektivitasnya. Selain itu perlu disediakan fasilitas belajar yang memadai, 
pembelajaran kewirausahaan disarankan menggunakan multi metode dan media pembelajaran yang dapat menunjang tercapainya tujuan pembelajaran.

\section{Daftar Rujukan}

Azwar, Saifudin. 2007. Sikap Manusia, Teori dan Pengukurannya. Yogyakarta Liberty.

Bell, Joseph R. Utilization of Problem Based-Learning in an Entrepreneurship Business Planning Course, New England Journal of Entrepreneurship, Spring 2008, pp 53

Drucker, F. Peter. Tanpa Tahun. Innovation and Entrepreneurship : practicer and principles. Penerjemahan Rusdi Naid. 1994. Jakarta: Gelora Aksara Pratama.

Ghozali, Imam. 2008. Aplikasi Analisis Multivariate dengan Program SPSS. Semarang: Badang Penerbit Undip.

Green, B.F. 1972. "Attitude Measurement". in G. Lindzey (ed), Handbook of Social Psychology. 1. 335-369. Reading, MA:Addision-Wesley.

Handriani, Eka. 2011. Pengembangan Kualitas Pendidikan Kewirausahaan di Perguruan Tinggi. Jurnal Ilmiah Inkoma, Volume 22, Nomor 1, Februari 2011

Indarti, Nurul dan Rokhima Rostiani. 2008. Intensi Kewirausahaan Mahasiswa:Studi Perbandingan Antara Indonesia, Jepang dan Norwegia.Jurnal Ekonomika dan Bisnis Indonesia, Vol. 23, No. 4, Oktober 2008.

Kourilsky, M.L. dan Walstad. W.B. 1998. Entrepreneurship and female youth: knowledge. attitude. gender differences, and educational practices. Journal of Business Venturing. 13 (1),77-88.

Mann, L. 1969. Social Psychology. Sydney: John Wiley dan Sons Australia PTY, Ltd.

Mednick. S.A. et.al. 1975. Exoloration in Behavior and Experience Psycholoqy. New York: John Wiley and Sons.

Meredith, Geoffrey G. Tanpa Tahun. Kewirausahaan: Teori dan Praktek. Penerjemah Andre Asparsayogi. 2005.Jakarta: PT. Pustaka Binaman Pressindo.

Mulyadi, Hari. 2010. Pengaruh Pendidikan Kewirausahaan Terhadap Sikap Kewirausahaan Serta Dampaknya Pada Perilaku Kewirausahaan Mahasiswa, Lembaga Penelitian dan Pengabdian kepada Masyarakat Universitas Pendidikan Indonesia. (http://penelitian.lppm.upi.edu/detil/1331/pengaruh-pendidikan-terhadap-sikap-kewirausahaanserta-implikasinya-pada-perilaku-kewirausahaan-mahasiswa), diakses 30 September 2013.

Rajasa, Hatta. 2013. Hatta: Kewirausahaan Penting untuk Membangun Bangsa. Dalam Republika. (online) (http://www.republika.co.id/berita/nasional/umum/13/02/09/mhy01d-hatta-kewirausahaanpenting-untuk-membangun-bangsa), diakses tanggal 30September 2013.

Secord, P.F. dan Backman, C.W., 1964. Social Psychology. New York: Mc. Graw Hill Book Company.

Tawardi, B. 1999. Sikap Kewirausahaan Anggota Kelompok Belajar Usaha dan Beberapa Faktor yang Mempengaruhinya. Bogor: IPB Press.

Walgito, Bimo. 2003. Pengantar Psikologi Umum. Yogyakarta: Andi Offset.

Johnson. 2003. Peranan Universitas dalam Memotivasi Sarjana Menjadi Young Entrepreneurs. Jurnal Manajemen dan Kewirausahaan, 5(2): 97-111.

Fayolle, A., Gailly, B. t., \& Lassas-Clerc, N. 2006. Assessing the impact of entrepreneurship education programmes: a new methodology. Journal of European Industrial Training, 30(8/9): 701-720 